\title{
Dampak Relokasi Pasar Terhadap Kondisi Sosial Ekonomi Pedagang Pasar Tente Kecamatan Woha Kabupaten Bima
}

\author{
M. Junaidi ${ }^{1}$, Ramayanto ${ }^{2}$, Nurlailatul ${ }^{3}$ \\ ${ }^{1}$ Prodi Administrasi Bisnis, Universitas Muhammadiyah Mataram, Indonesia \\ 2Prodi Administrasi Bisnis, Universitas Muhammadiyah Mataram, Indonesia \\ ${ }^{3}$ Prodi Administrasi Bisnis, Universitas Muhammadiyah Mataram, Indonesia
}

\section{INFO ARTIKEL}

\section{Riwayat Artikel:}

Diterima: 01-03-2018

Disetujui: 05-03-2018

\section{Kata Kunci:}

1. Relokasi

2. Perubahan Interaksi

3. Dampak sosial

4. Ekonomi

\section{Keyword:}

1. Relocation

2. Interaction change

3. Socio Impact

4. Economic

\section{ABSTRAK}

Abstrak: Pasar merupakan salah satu lembaga yang paling penting dalam institusi ekonomi. Berfungsinya lembaga pasar sebagai institusi ekonomi yang menggerakkan kehidupan ekonomi tidak terlepas dari aktivitas yang dilakukan oleh pedagang dan pembeli. Rumusan masalah yaitu, Bagaimana Dampak Sosial Ekonomi terhadap relokasi Pasar Tente. Penelitian ini bertujuan untuk mendeskripsikan Dampak Relokasi Pasar Terhadap Kondisi Sosial Ekonomi Pedagang Pasar Tente. Penelitian ini menggunakan metode kualitatif deskriptif.

Hasil penelitian ini menunjukkan bahwa, adanya perubahan sosial, dimana secara teknis pedagang dan lokasi berdagang dari pasar lama berpindah ke pasar baru. Dalam perpindahan pasar ini memunculkan dampak, yaitu dampak sosial dan ekonomi seperti manifestasi, dengan adanya dampak manifestasi, maka muncul dampak di belakangnya yaitu, dampak latensi yang dialami oleh pedagang setelah relokasi pasar. Serta kurang intennya interaksi yang terjalin antara pedagang lama dan pedagang baru. Dampak sosial yang muncul yaitu, berubahnya sistem sosial, interaksi dan hubungan personal yang kurang. Dampak ekonomi yang muncul yaitu tentang pendapatan yang menurun setelah menempati pasar Tente yang baru.

\section{Abstract}

The market is one of the most important institutions in economic institutions. The functioning of market institutions as economic institutions that drive economic life can not be separated from the activities undertaken by traders and buyers. The formulation of the problem is, How the SocioEconomic Impact on Tente Market relocation. This study aims to describe the Impact of Market Relocation to Socio-Economic Conditions of Tente Market Traders. This research uses descriptive qualitative method.

The results of this study indicate that, there is a social change, which technically traders and locations trade from the old market move to new markets. In this market shift raises the impact, ie social and economic impacts such as manifestations, with the impact of manifestations, the impact behind them is the latency impact experienced by traders after the relocation of the market. And less intennya interaction that exists between old traders and new traders. The social impacts that arise are the lack of social systems, interactions and personal relationships. The emerging economic impact of declining income after occupying the new Tente market. 


\section{Latar Belakang}

Pembangunan adalah salah satu tujuan penting dalam suatu tata kelola. Dan tujuan utama pembangunan adalah meningkatkan kualitas hidup manusia sehingga Untuk mencapai tujuan tersebut, maka pembangunan perlu mekanisme atau metode tertentu agar dapat meningkatkan kualitas hidup manusia dan suatu pedoman mekanisme, metode, cara dalam pelaksanaan pembangunan tersebut yang di pahami sebagai kebijakan.

Pembangunan adalah alasan utama dari kebijakan relokasi Pasar Tente sehingga untuk sementara waktu akan di revitalisasi. Jika dilihat lebih lanjut, kebijakan relokasi ini menunjukan pada kita bahwa dalam pembuatan kebijakan ada stakeholder yang dapat mempengaruhi arah kebijakan selain pemerintah, stakeholder tersebut adalah pemilik modal besar atau investor dan bisa juga masyarakat yang sehari-hari terlibat dalam dinamika pasar.

Pasar merupakan tempat pertemuan antara penjual dan pembeli, pasar merupakan salah satu lembaga yang paling penting dalam institusi ekonomi dan salah satu penggerak dinamika kehidupan ekonomi. Berfungsinya lembaga pasar sebagai institusi ekonomi tidak terlepas dari aktifitas yang dilakukan oleh penjual dan pembeli (Damsar dalam Yulianti, 2011: 3). Saat ini, pasar tidak hanya menjadi tempat terjadinya transakasi jual beli, tetapi pasar juga mulai dijadikan sarana penggerak perekonomian, dinamika perekonomian suatu kota atau kabupaten ditentukan oleh seberapa jauh efisiensi penggunaan ruang atau pola.

Penggunaan ruang untuk aktifitas perekonomian di kota atau kabupaten tersebut. Perkembangan perekonomian kota atau kabupaten ini secara spesifik akan ditentukan oleh dinamika sistem perdagangan yang ada di kota atau kabupaten itu dan juga di kawasan sekitarnya (Kiik dalam Setyaningsih) dan Susilo, 2014: 1).

Sampai saat ini, sarana perdagangan yang masih tetap eksis di lingkungan perdesaan maupun perkotaan adalah pasar tradisional. Ada 4 fungsi ekonomi yang dapat diperankan pasar tradisional, yaitu:

1. Pasar tradisional merupakan tempat dimana masyarakat dari berbagai lapisan memperoleh barang-barang kebutuhan harian dengan harga yang relatif terjangkau, karena seringkali relatif lebih murah dibandingkan dengan harga yang ditawarkan pasar modern. Dengan kata lain bahwa pasar tradisional merupakan pilar penyangga ekonomi masyarakat kecil.

2. Pasar tradisional merupakan tempat yang relatif bisa dimasuki oleh pelaku ekonomi lemah yang menempati posisi mayoritas, terutama yang bermodal kecil.

3. Pasar tradisional merupakan salah satu sumber pendapatan asli daerah, lewat retribusi yang ditarik dari para pedagang.

4. Akumulasi aktivitas jual beli di pasar merupakan faktor penting dalam perhitungan tingkat ekonomi baik pada skala lokal, regional maupun nasional.

Selain fungsi ekonomi di atas, pasar tradisional juga mempunyai fungsi sosial, yaitu:

1. Pasar tradisional merupakan ruang untuk saling bertemu muka.

2. Pasar tradisional adalah tempat bagi masyarakat, terutama dari kalangan bawah, untuk melakukan interaksi sosial dan tukar informasi atas segenap permasalahan yang mereka hadapi (Blokosuto, Edisi 02 dalam Endrawanti, 2012: 78-79).

Pasar Tente terletak di jalan lintas Tente Cenggu Kecamatan Woha, Kabupaten Bima. Pasar Tente merupakan Pasar Umum terbesar yang ada di Kabupaten Bima. Keberadaan Pasar Tente ini merupakan salah satu dari berbagai sumber peningkatan pereonomian Kabupaten Bima, khususnya bagi masyarakat Kecamatan Koha Kabupaten Bima, karena sebagian besar masyarakat menggantungkan hidupnya dari penghasilannya sebagai pedagang di Pasar Tente. Pasar ini tidak hanya melibatkan masyarakat Kecamatan Woha saja sebagai penjual dan pembeli, tetapi juga masyarakat yang ada diluar Kecamatan Woha seperti masyarakat di perdesaan misalnya Desa Cenggu Desa Keli Desa Risa dan masih banyak lagi.

Dalam rangka mengoptimalkan fungsi pasar, pemerintah Kabupaten Bima menerapkan kebijakan berupa revitalisasi. Salah satu bentuk kebijakan revitalisasi pasar adalah relokasi yaitu pemindahanlokasi pasar dari satu tempat ke tempat yang lain. Berdasarkan kebijakan Pemerintah Kabupaten Bima, pada tahun 2016 dilakukan pemindahan lokasi (relokasi) pada salah 
satu pasar Umum di Kabupaten Bima. Pasar Tente merupakansalah satu icon pasar Umum yang berada di Kabupaten Bima.

Relokasi Pasar Tente ini bertujuan untuk menata lokasi perdagangan yang disesuaikan dengan barang dagangannya, sehingga lebih teratur dan tertib.Selain itu, relokasi ini juga bertujuan untuk meningkatkan kesejahteraan para pedagang di Pasar Tente.Walaupun pemindahan lokasi pasar tidak jauh dari lokasi Pasar Tente lama, namun tetap saja ada perbedaan yang dirasakan oleh para pedagang dan juga masyarakat yang melakukan kegiatan jual-beli di Pasar umum Tente.

Adanya kebijakan pemerintah terkait relokasi pasar ini tentunya memunculkan banyak pendapat dari berbagai kalangan masyarakat.Disuatu kelompok masyarakat terdapat kelompok yang dinamakan sebagai kelompok masyarakat tertutup dan kelompok masyarakat terbuka. Adanya dua kelompok tersebut akan menimbulkan persepsi yang berbeda denganadanya kebijakan tentang relokasi pasar Tente. Keaadaan demikian pasti akan menimbulkan banyak pendapat yang berbeda pula. Adanya suatu perubahan dalam masyarakat, pasti juga menimbulkan berbagai macam pendapat.

Lokasi yang baru ini sebenarnya sangat strategis dan rapi secara struktur baik tempat dan penggolongan jenis pedagang.Namun, pedagang baru yang tidak mempunyai tempat berdagang ikut berjualan di lorong pasar.Selain hal tersebut tidak mudah para pedagang bisa menerima sepenuhnya perubahan ini dengan cepat, dikarenakan membutuhkan waktu yang cukup lama untuk bisa berubah dalam tahap penyesuaian.

Relokasi ini memiliki tujuan diantaranya agar pasar Tente tidak ditinggalkan para konsumen karena penataan lokasi yang kurang optimal serta diharapkan dengan pemindahan lokasi pasar ke tempat yang lebih strategis ini dapat meningkatkan kualitas pelayanan dan daya tampung pedagang serta pembeli. Peningkatan daya tampung tersebut diharapkan dapat membantu pedagang Pasar Tente agar dapat mengembangkan usahanya dan meningkatkan kesejahteraan pedagang.Pada dasarnya kegiatan relokasi memiliki dampak positif dan negatif baik dilihat dari sisi sosial maupun ekonomi terhadap para pelaku ekonomi di dalamnya.

Mengingat adanya berbagai kemungkinan dampak positif dan negatif yang dapat ditimbulkan dari kegiatan relokasi pasar Tente, maka peneliti akan melakukan penelitian Dampak relokasi pasar terhadap kondisi sosial ekonomi pedagang pasar tente. Kondisi sosial yang dimaksudkan dalam penelitian ini adalah permasalah sosial kaitannya dengan Interaksi sosial pedagang, dimana interaksi sosial adalah hubungan timbal balik antara satu pedagang dengan pedagang lainnya, seperti: kerjasama, persaingan, dan konflik. Sedangkan Kondisi ekonomi yang dimaksud dalam penelitian ini yaitu pendapatan pedagang pasar tente setelah adanya relokasi pasar, dan juga dampak relokasi terhadap pemenuhan kebutuhan hidup pedagang. Sejak tahun 2014 kabupaten bimalah yang mengalami kenaikan kemiskinan dari 73.832 jiwa pada tahun 2014 menjadi 74.540 jiwa pada tahun 2016 (BPS, kabupaten bima Dalam Angka 2016) jika dilakukan kebijakan relokasi pasar atau kehadiran retail modern di kabupaten Bima maka tentu angka kemiskinan semakin meningkat seiring dengan semakin banyak nya pedagang - pedagang baru yang masuk dan semakin banyaknya PKL yang kalah saing dengan retail modern. Dalam Asumsi makro ekonomi, hal ini menciptakan semakin banyaknya pengangguran akibat dari banyak nya pedagang pedagang lama yang tidak mendapatkan tempat berjualan yang gulung tikar setiap tahunnya. Semakin banyak pengangguran maka tentu tingkat kriminalitas akan semakin meningkat mengingat kebutuhan ekonomi yang tidak terpenuhi, kemudian konsumsi rumah tangga berkurang karena pendapatan minus, investasi domestic tidak berjalan karena tabungan minim akibat dari pendapatan minus, PDRB menurun karena angka pengangguran meningkat dan angka kemiskinan akan meningkat pula. Lihat saja PDRB tiga tahun terakhir dari sektor perdagangan kabupaten bima ini menurun. Yang 
semulanya di tahun 2015 sebanyak 1419740 sedangkan di tahun 2016 menjadi 1277611 dan di tahun 2017 sangat menurun menjadi 1143710 (BPS Dalam angka 2017).

Adapun beberapa fenomena - fenomena yang terjadi di pasar tente setelah di lakukan relokasi tersebut sehingga peneliti tertarik untuk melakukan penelian tentang dampak relokasi pasar terhadap kondisi sosial ekonomi pedagang Pasar Tente baru - baru ini yaitu kurang teraturnya tata letak pedagang di lokasi baru Pasar Tente, yang dikarenakan masuknya pedagang-pedagang dari luar, Terdapat pro dan kontra tentang kesepakatan relokasi pasar antara pedagang dengan kebijakan relokasi, Lamanya adaptasi pasca relokasi bagi pedagang untuk menarik kembali para konsumen, Banyaknya pendapat mengenai relokasi pasar menyebabkan lamanya proses sosialisai relokasi pasar, Terjadinya perubahan pasar baik berupa nilai dan norma sosial mempengaruhi dampak sosial dan ekonomi para pedagang dan masyarakat sekitar. Selain itu terkait status pedagang tradisional yang dulu bersatu dalam satu tempat kini pedagang tradisional terpecah-pecah ada yang menempati lokasi pasar paling belakang sebagai pedagang grosir, dan sebagian ada juga pedagang yang berdagang diluar area Pasar Tente.Sehingga hal tersebut berpengaruh pada kehidupan sosial ekonomi pedagang Pasar Tente.

\section{Tinjauan pustaka}

\section{a. Pengertian relokasi}

Teori lokasi adalah ilmu yang menyelidiki tata ruang kegiatan ekonomi, atau ilmu yang menyelidiki alokasi geografis dari sumbersumber yang potensial, serta hubungannya dengan atau pengaruhnya terhadap keberadaan berbagai macam usaha atau kegiatan lain baik ekonomi maupun sosial. Lokasi berbagai kegiatan seperti rumah tangga, pertokoan, pabrik, pertanian, pertambangan, sekolah dan tempat ibadah tidaklah asal saja atau acak berada di lokasi tersebut, melainkan menunjukkan pola dan susunan yang dapat diselidiki dan dapat dimengerti (Tarigan dalam Setyaningsih, 2014: 5).

Pengertian relokasi dalam kamus Indonesia diterjemahkan relokasi adalah membangun kembali perumahan, harta kekayaan, termasuk tanah produktif, dan prasarana umum di lokasi atau lahan lain. Dalam relokasi adanya objek dan subjek yang terkena dampak dalam perencanaan dan pembangunan relokasi (Sari, 2006: 2).

Relokasi merupakan pemindahan suatu tempat ke tempat yang baru.Relokasi adalah salah satu wujud kebijakan pemerintah daerah yang termasuk dalam kegiatan revitalisasi. Revitalisasi dalam Kamus Besar Bahasa Indonesia (KBBI) berarti proses, cara, dan perbuatan menghidupkan kembali suatu hal yang sebelumnya kurang terberdaya (Setyaningsih dan Susilo, 2014: 5).

Menurut Musthofa (2011: 17) Lokasi dan tempat relokasi baru adalah faktor penting dalam perencanaan relokasi, karena sangat menentukan kemudahan menuju lahan usaha, jaringan sosial, pekerjaan, bidang usaha, kredit dan peluang pasar. Setiap lokasi mempunyai keterbatasan dan peluang masing-masing. Memilih lokasi yang sama baik dengan kawasan yang dahulu (tempatnya yang lama) dari segi karakteristik lingkungan, sosial budaya dan ekonomi akan lebih memungkinkan relokasi dan pemilhan pendapatan berhasil. Musthofa (2011: 17) Idealnya tempat relokasi baru sebaiknya secara geografis dekat dengan tempat lama asli untuk mempertahankan jaringan sosial dan ikatan masyarakat yang sudah baik.

\section{b. Pasar Tradisional}

Pasar tradisional adalah pasar yang bersifat tradisional dimana para penjual dan pembeli dapat mengadakan tawar menawar secara langsung.Barang-barang yang diperjual belikan adalah barang yang berupa barang kebutuhan pokok (Lufti, 2012: 4). Menurut Wicaksono, dkk (2008), bahwa pasar tradisional merupakan tempat bertemunya penjual dan pembeli serta ditandai dengan adanya transaksi penjual pembeli secara langsung, bangunan biasanya terdiri dari kios-kios atau gerai, los dan dasaran terbuka yang dibuka oleh penjual atau suatu pengelola pasar.

Wiryomartono (dalam Endrawanti, 2012: 80) mengemukakan bahwa, pasar tradisional adalah kejadian yang berkembang secara periodik, dimana yang menjadi adalah interaksi sosial dan ekonomi dalam suatu peristiwa.Pasar berasal dari kata "peken" yang berarti kumpul.

Menurut peraturan menteri perdagangan republik Indonesia nomor 70/MDAG/PER/12/2013 tentang pedoman penataan dan pembinaan pasar tradisional, pusat perbelanjaan dan dan toko modern, dalam Bab I ayat 3 bahwa pasar tradisional adalah pasar yang 
dibangun dan dikelola oleh pemerintah, pemerintah daerah, swasta, Badan Usaha Milik Negara dan Badan Usaha Milik daerah, termasuk kerjasama dengan usaha dengan tempat usaha berupa toko, kios, los, dan tenda yang dimiliki/dikelola oleh pedagang kecil, menengah, swadaya masyarakat, atau koperasi dengan usaha skala kecil, modal kecil, dan dengan proses jul beli barang dagangan melalui tawar menawar.

\section{c. Kondisi sosial ekonomi}

Sosial ekonomi merupakan segala sesuatu yang berkaitan dengan pemenuhan kebutuhan yang ada dimasyarakat atau yang lebih umumnya terkait dengan kesejahteraan masyarakat, untuk melihat kondisi sosial ekonomi Melly G.Tan mengatakan dapat dilihat dari pekerjaan, pendidikan, kesehatan, dan pemenuhan kebutuhan hidup dalam rumah tangga. Berdasarkan ini, masyarakat dapat digolongkan kondisi sosial ekonomi atas, menengah dan bawah (Koentjaraningrat dalam Zunaidi, 2013: 54).

Notoadmodjo (dalam Bachrir, 2013: 7) mengemukakan sosial ekonomi adalah suatu konsep, dan untuk mengukur sosial ekonomi harus melalui variable-variabel pendapatan keluarga, tingkat pendidikan dan pekerajaan. Menurut Suparyanto (dalam Bachrir, 2013: 7) sosial ekonomi adalah gambaran suatu keadaan seseorang atau suatu masyarakat yang ditinjau dari segi sosial ekonomi.Gambaran itu seperti tingkat pendidikan, pendapatan dan sebagainya.

Kondisi sosial ekonomi adalah suatu kedudukan yang diatur secara sosial dan menempatkan seseorang pada posisi tertentu dalam masyarakat, pemberian posisi itu disertai pula dengan seperangkat hak dan kewajiban yang harus dimainkan oleh si pembawa status (Sumardi dalam Juariyah dan Basrowi, 2010: 60).

Dari uraian di atas, dapat disimpulkan bahwa, kondisi sosial ekonomi adalah kondisi seseorang yang dapat diukur dari pendidikannya, pekerjaan, pendapatan, dan lain-lain.

\section{d. Pendapatan}

Winardi dalam Ajemain (2012: 16) mengemukakan bahwa pendapatan adalah hasil berupa uang atau hasil lainnya yang dicapai dari pada penggunaan kekayaan jasa atas manusia. Hal ini mengandung arti bahwa pendapatan merupakan sesuatu yang diperoleh karena pemanfaatan sesuatu yang lain yaitu pengunaan kekayaan dan jasa-jasa tersirat juga adanya kemampuan dan keterampilan mengelola faktor- faktor tersebut untuk mendapatkan materi berupa kekayaan atau barang.

Boediono (dalam Aisah, 2015: 20) memberikan pengertian pendapatan atau income dari seseorang adalah hasil penjualan dari faktorfaktor produksi yang ditentukan oleh dua hal, yaitu jumlah faktor-faktor atau kekayaan yang dimiliki, dan harga jual perunit dari setiap kekayaan faktor-faktor produksi.Menurut Sukirno (dalam Aisah, 2015: 20) mengatakan bahwa, pendapatan adalah berupa uang materi atau keduanya yang timbul karena penggunaan faktor produksi.Pendapatan pada hekekatnya merupakan balas jasa dari faktor produksi yang didalamnya upah, sewa tanah, bunga modal, laba dan pensiun.

\section{Metode penelitian}

Penelitian ini menggunakan metode kualitatif deskriptif. Sumber utama dari penelitian ini adalah pedagang serta pengelola pasar. Teknik pengumpulan data yang digunakan adalah dengan wawancara (interview), pengamatan (observasi), dan dokumentasi. Untuk memperoleh informan, penelitian ini menggunakan teknik purposive sampling. Validitas data yang digunakan dalam penelitian ini antara lain triangulasi, Sedangkan teknik analisis data yang digunakan adalah teknik analisis kualitatif model interaktif sebagaimana diajukan oleh Miles dan Huberman.

\section{Hasil dan Pembahasan}

\section{Dampak sosial ekonomi pasar tente Yang terjadi setelah di lakukan relokasi.}

Berdasarkan hasil penelitian, penulis mencoba menganalisis Dampak Relokasi Pasar terhadap Kondisi Sosial Ekonomi Pedagang berdasarkan persepsi dari beberapa narasumber yang sudah peneliti wawancarai dengan mengajukan 19 pertanyaaan secara terstruktur. Kondisi sosial pedagang dalam penelitian ini di ukur berdasarkan permasalahan sosial (interaksi pedagang), seperti konflik, kerjasama, dan persaingan sedangkan kondisi ekonomi di ukur berdasarkan pendapatan pedagang.

Masyarakat selalu mengalami perubahan dalam dinamika kehidupan. Selama masih ada manusia pasti ada kebudayaan, dalam kebudayaan, pasti memunculkan inovasi dan akan mengalami perubahan seiring dengan berjalannya waktu. Ada perubahan yang lambat serta perubahan yang cepat.Perubahan lambat 
yang dimaksudkan ialah ketika pedagang harus berusaha kembali untuk menarik pelanggan lama yang sebelumnya sudah menjadi pelanggan tetap pada saat masih berada di Pasar Tente Lama. Contoh lain dari perubahan lambat dalam hal pendapatan yaitu, setelah relokasi pedagang harus menata kembali perekonomiannya, dan membutuhkan proses untuk mengembalikan laju pendapatan seperti dahulu. Untuk perubahan cepat berupa keadaan fisik pasar yang sudah modern dan tertata rapi dengan berbagai fasilitas yang layak untuk digunakan, baik untuk pedagang maupun bagi pengunjung. Perubahan masyarakat dapat mengenai nilai dan normanorma sosial pola perilaku organisasi susunan lembaga kemasyarakatan dan lain sebagainya. Pada pembahasan ini perubahan sosial yang terjadi akibat relokasi tempat perdagangan Pasar Tente yang secara otomatis mempengaruhi kondisi fisik, serta adanya tujuan untuk tata letak Kabupaten agar lebih rapi. Selain tata letak Kabupaten, relokasi pasar ini bertujuan sebagai pembangunan ekonomi. Perubahan-perubahan yang terjadi pada masyarakat dewasa ini merupakan gejala yang normal. Pengaruhnya bisa menjalar dengan cepat ke bagian-bagian lain, berkat adanya komunikasi modern. Perubahan dalam masyarakat memang telah ada sejak zaman dahulu. Relokasi pasar ini akan memunculkan dampak yang bermacam-macam. Pedagang yang tadinya bertempat di Pasar Lama dan tata letak para pedagang terkesan berdesakdesakan sekarang telah berubah menjadi pasar yang lebih modern.

Kini Pasar Tente yang mengalami banyak perubahan, baik dari segi ekonomi, lokasi, dan daya tarik pasar dikarenakan karateristik yang sangat unik. Pasar Tente sekarang mempunyai tempat yang sangat bersih dan indah berbeda dengan pasar Tente yang dahulu, karena pasar Tente yang dahulu untuk segi tempat kurang bersih dan terkesan kumuh. Sekarang di dalam Pasar Tente terdapat fasilitas yang baik dan sangat layak untuk dinikmati para pengunjung.Seperti tempat beribadah yang berada di Bagian Pinggir pasar, serta area parkir yang luas dan memadai. Berbagai macam pendapat muncul dengan adanya relokasi pasar ini. Munculnya banyak pendapat akan kurang setujunya pedagang Pasar Tente dengan dilaksanakannya relokasi pasar ini, meskipun akhirnya para pedagang tetap berpindah ke lokasi yang baru. Terjadi konflik yang tidak terlalu terlihat (laten) karena ketidaksetujuan ini tidak diutarakan dan hanya penolakan dalam hati.
Pola kebudayaan yang melatarbelakangi pembentukan serta perkembangan kepribadian tersebut memunculkan Pendapat bahwa pasar yang sudah lama dan berjalan turun temurun itulah yang menjadikan rasa nyaman dan menganggap keuntungan itu sudah terbentuk dengan seiring berjalannya waktu. Apabila dipindah anggapan akan adaptasinya yang lama dan memulai segala sesuatunya itu dari awal.

Adanya hubungan antar pedagang satu dengan pedagang lain merupakan reaksi yang ditimbulkan karena adanya kontak secara langsung maupun secara tidak langsung. Hubungan timbal balik (aksi dan reaksi) inilah yang kita sebut interaksi sosial. Hubunganhubungan dinamis yang menyangkut hubungan antara individu dengan individu, antara individu dengan kelompok, atau antara kelompok dengan kelompok, baik berbentuk kerja sama, persaingan, ataupun pertikaian. Dalam pembahasan ini terdapat suatu fenomena yang menarik yaitu, persaingan antara pedagang lama yang telah berpindah dan pedagang baru atau musiman yang masuk ke dalam pasar Tente baru, lebih tepatnya adalah persaingan ekonomi dalam mendapatkan keuntungan. Para pedagang lama sebagian merasa keberatan dengan adanya pedagang-pedagang baru atau biasa disebut dengan pedagang musiman, namun para pedagang lama hanya diam saja karena menganggap bahwa sama-sama mencari makan. Hanya saja pada saat tertentu pedagang lama sering kurang mendapat konsumen pada saat hari besar pasar atau hari libur seperti pada hari Minggu, atau Sabtu. Sebenarnya pedagang baru atau musiman ini tidak diperbolehkan masuk pasar akan tetapi keadaan yang mendesak dan sama-sama mencari makan akhirnya para pedagang lama tidak bisa berbuat banyak.

Dalam hubungan interaksi yang terjadi diantara pedagang lama dengan pedagang baru kurang memiliki hubungan yang inten, hanya sebatas kenal begitu saja. Sesuai dengan hasil wawancara bahwa pedagang lama menjalin interaksi sekedar dengan tetangga kios, jarang yang kenal antara kios yang satu dan yang lainya karena faktor tempat yang berjauhan dan juga dengan pedagang baru hanya sebatas kenal saja tidak terlalu akrab.

Dapat pula dianalisis bahwa terdapat bentuk interaksi yang bersifat disosiatif, yaitu dengan jenis persaingan merujuk pendapat Gillin dan Gillin mengenai bentuk-bentuk interaksi sosial. Persaingan terjadi antara pedagang yang berada di kios, dengan pedagang baru. 
Terdapat persaingan antara pedagang lama dan pedagang baru dalam hal meraih keuntungan.Pada saat hari libur pedagang musiman yang masuk otomatis menarik para pengunjung yang seharusnya mengunjungi kios, lari ke pedagang musiman. Sebenarnya pedagang musiman ini tidak diperbolehkan berjualan di lokasi pasar Tente, tetapi dengan alasan samasama mencari makan maka muncullah toleransi dari pedagang yang ada di kios. Ini memunculkan dampak bagi para pedagang yang berada di kios. Tidak semuanya yang dijual pedagang musiman itu murah, hanya kesannya saja murah, tetapi jika memang kualitas barang dagangan yang dijual pedagang musiman lebih bagus maka istilahnya untung-untungan bagi para pengunjung yang membeli barang tersebut. Pedagang yang tidak mempunyai pelanggan tetap dan servis tempat maupun barang yang berkualitas maka akan kalah saing dengan pedagang musiman dan menimbulkan dampak ekonomi bagi para pedagang yang berada di kios. Adapun dampak sosial ekonomi yang muncul, dampak sosial ekonomi yang muncul setelah perelokasian pasar, juga menjadi hal menarik perhatian seperti pendapatan yang awalnya bisa dikatakan melebihi rata-rata sekarang agak berkurang.

Faktor waktu juga mempengaruhi pendapatan karena masyarakat yang kurang begitu mengenal lokasi pasar yang baru. Untuk pendapatan lumayan bisa untuk makan memang tidak tentu pendapatan perhari itu berapa. Pada awal perpindahan lokasi pasar ke lokasi yang baru belum banyak yang tahu, tetapi sekarang sudah mulai kembali sedikit demi sedikit seiring dengan berjalanya waktu lama-lama pasti banyak yang tahu.

Dampak secara etimologis dampak sosial merupakan suatu benturan atau tubrukan dari sesuatu hal, sedangkan secara sosiologis dampak sosial merupakan sebuah dasar untuk menelaah sebuah gejala sosial. Menurut artinya dampak sosial adalah sebuah akibat dari sebuah fenomena sosial yang terjadi dalam kehidupan masyarakat. Kajian dari dampak sosial sendiri tidak hanya fenomena sosial yang terjadi di masyarakat saja, tetapi juga aktifitas-aktifitas atau kegiatan-kegiatan yang dilakukan mempunyai konsekuensi tersendiri yang bersifat positif maupun negatif. Peneliti menggunakan pendapat Soerjono soekanto mengenai dampak sosial yang terbagi menjadi dua yaitu Manifestasi yang mempuyai arti sebuah kecenderungan harapan yang diinginkan dari suatu proses sosial yang terjadi, sedangkan Latency sebagai bentuk yang tidak diharapkan, tetapi secara alamiah selalu menyertai atau muncul.

Sebagai hasil dari analisis maka peneliti akan menggambarkan dampak sosial menggunakan tabel sebagai berikut:

\section{Tabel 1}

Dampak Sosial

\begin{tabular}{|c|c|}
\hline Manifestasi & \\
\hline $\begin{array}{l}\text { Dari segi lokasi yang } \\
\text { bermula sempit, } \\
\text { sekarang menjadi luas. }\end{array}$ & $\begin{array}{l}\text { Setelah relokasi, untuk } \\
\text { pengunjung berkurang }\end{array}$ \\
\hline $\begin{array}{lr}\text { Dari lokasi } & \text { yang } \\
\text { bermula } & \text { kumuh } \\
\text { sekarang } & \text { menjadi } \\
\text { tempat yang bersih dan } \\
\text { nyaman }\end{array}$ & $\begin{array}{l}\text { Pendapatan pedagang } \\
\text { berkurang. }\end{array}$ \\
\hline $\begin{array}{l}\text { Pedagang lebih tertata } \\
\text { dengan pengalokasian } \\
\text { tempat yang sudah } \\
\text { digolongkan } \\
\text { berdasarkan jenis barang } \\
\text { dagangan seperti, } \\
\text { pakaian, sayur-sayuran } \\
\text { dll }\end{array}$ & $\begin{array}{l}\text { Interaksi antar } \\
\text { pedagang berkurang. }\end{array}$ \\
\hline $\begin{array}{l}\text { Fasilitas lain seperti } \\
\text { (mushola, kamar mandi, } \\
\text { Wc, dan tempat parkir } \\
\text { yang memadahi }\end{array}$ & \begin{tabular}{lr} 
Masih & \multicolumn{2}{c}{ banyak } \\
pelanggan yang sulit \\
menemukan lokasi \\
langganannya \\
masing
\end{tabular} \\
\hline $\begin{array}{llr}\text { Akses lebih mudah } \\
\text { dijangkau dari mana } \\
\text { saja. }\end{array}$ & $\begin{array}{lr}\text { Pedagang } & \text { terpetak- } \\
\text { petak. sehingga } & \text { untuk } \\
\text { pedagang } & \text { hanya } \\
\text { berinteraksi } & \text { dengan } \\
\text { pedagang kios } & \\
\end{array}$ \\
\hline $\begin{array}{l}\text { Dalam persaingan } \\
\text { perdagangan pedagang } \\
\text { bersaing secara sehat. }\end{array}$ & $\begin{array}{l}\text { Hubungan personal } \\
\text { antar pedagang kurang } \\
\text { inten. }\end{array}$ \\
\hline
\end{tabular}

Suatu perubahan yang terjadi dalam kehidupan masyarakat pastilah akan mempengaruhi bagian-bagian kehidupan yang lainnya pula, baik itu yang diharapkan maupun yang tidak diharapkan. Program relokasi pasar direncanakan oleh pemerintah merupakan suatu bentuk kegiatan yang mempunyai tujuan atau 
orientasi tertentu dan juga bersifat positif ataupun progress selain dampak yang bersifat positif juga terdapat pula dampak yang negative yang muncul. Jelas untuk dampak yang bersifat positif dapat dirasakan bagi para pedagang dengan keadaan yang lebih nyaman dan terjamin.selain itu dampak positif yang dirasakan masyarakat sekitar yaitu, dengan adanya pasar yang baru masyarakat yang berprofesi seagai pedagang dan masyarakat yang tadinya tidak berdagang, kini ikut berdagang didalam pasar. Masyarakat tersebut tidak berdagang tetap melainkan berdagang kuliner dalam pasar dengan tujuan menyediakan berbagai macam makanan ringan maupun nasi beserta lauk pauk. Selain berdagang kuliner, dampak positif lainya seperti pedagang kaki lima yang biasanya berdagang keliling mulai mangkal di pasar karena lebih bisa mendapat keuntungan dengan tanpa keliling lagi.

Untuk dampak negatif yang muncul adalah munculnya suatu konflik intern pedagang setempat dengan adanya pelaksanaan relokasi pasar. Contoh dampak negatif yang lain yaitu dengan adanya sistem atau peraturan yang baru pada pasar, para pedagang kurang tau tentang peraturan-peraturan yang dibuat seperti terjadi sosialisasi yang kurang sempurna. Awalnya, banyak yang tidak setuju dengan adanya pemindahan pasar, namun dengan seiring berjalanya waktu sosialisasi yang diberikan kepada pedagang lambat laun diterima dan akhirnya pedagang mau untuk dipindah. Proses dari pada sosialisasi ini yaitu melibatkan pedagang dari diadakanya sarasehan, dan setelah itu bagi pedagang yang tidak ikut diberi penjelasan dari pengurus paguyuban pasar.

\section{Simpulan}

$\begin{array}{cccc} & \text { Pasar merupakan salah satu lembaga yang } \\ \text { paling } & \text { penting } & \text { dalam } & \text { institusi }\end{array}$ ekonomi.Berfungsinya lembaga pasar sebagai institusi ekonomi yang menggerakkan kehidupan ekonomi tidak terlepas dari aktivitas yang dilakukan oleh pedagang dan pembeli. Relokasi Pasar Tente memunculkan berbagai macam pendapat dan dampak yang timbul. Berdasarkan pembahasan yang peneliti paparkan maka peneliti dapat menjawab pertanyaan dari rumusan masalah yang peneliti simpulkan sebagai berikut:

a. Dampak Sosial

Perubahan sosial yang terjadi setelah relokasi pasar Tente. Setiap manusia selama hidup pasti mengalami perubahan, perubahan tersebut dapat berupa perubahan yang tidak mencolok, ada pula perubahan yang pengaruhnya terbatas maupun yang luas.Ada perubahan yang lambat dan perubahan yang cepat. Adanya Relokasi Pasar Tente merupakan perubahan yang tergolong cepat dimana pasar beserta pedagang berpindah tempat ke lokasi pasar yang baru. Untuk segi lokasi pasar yang baru, lebih tertata dengan rapi dengan pengalokasian tempat berdagang sesuai dengan jenis barang yang diperdagangkan.Misalnya untuk pedagang Pecah Belah, Sayuran, Pakaian dll ada tanda tersendiri.

Interaksi antara pedagang baru dan pedagang lama di Pasar Tente Terdapat persaingan dalam meraih keuntungan antara pedagang lama dan pedagang baru. Terdapat interaksi yang kurang begitu kuat karena pedagang yang lama dan baru tidak saling mengenal. Hal tersebut dapat terjadi antara pedagang lama dan pedagang baru dikarenakan pedagang baru ini masuk ke lokasi pasar Tente sesuai dengan musim ramai pengunjung atau pada saat hari libur.Pedagang hanya berinteraksi dengan pedagang yang lokasi kiosnya berdekatan, sedangkan untuk pedagang yang agak berjauhan kurang saling kenal dan berinteraksi.

b. Dampak Eknomi

Adanya penetapan relokasi pasar yang baru menjadikan berbagai macam dampak yang muncul baik dampak sosial maupun ekonomi. Perpindahan pasar ini menuntut pedagang untuk cepat pula dalam tahap penyesuaian dengan pedagang dan lokasi pasar yang baru ini. Dampak sosial yaitu terbukanya lapangan pekerjaan baru seperti adanya tukang parkir, petugas kebersihan,petugas keamanan pasar. Segi yang lain yaitu kelengkapan fasilitas umum seperti bangunan mushola dan Wc. Pedagang harus beradaptasi untuk menghadapi hal yang baru pula seperti dampak ekonomi yang timbul seperti penurunan pendapatan rata-rata meskipun lambat-laun pendapatan itu perlahan kembali pulih seiring dengan berjalannya waktu.

\section{Saran}

Penelitian tentang dampak relokasi pasar terhadap kondisi Sosial ekonomi pedagang 
menjadikan dasar untuk memberikan saran sebagai berikut:

a. Bagi Pedagang

Demi terciptanya keadaan yang damai dan nyaman, maka untuk pedagang harus lebih bisa berinteraksi dengan pedagang-pedagang yang lain. Harapannya dengan demikian tercipta hubungan yang baik antara pedagang, serta tetap menjaga kebersihan lingkungan.

b. Bagi Pemerintah Setempat

Lebih memperhatikan perkembangan pasar agar bisa mengetahui dampak yang ditimbulkan setelah relokasi bagi pedagang.Demi terciptanya pasar yang lebih kondusif dan tata letak yang selalu rapi, pemerintah memperhatikan tempat dan kenyamanan bagi pedagang agar selalu dapat menarik para pengunjung.

c. Bagi Pengelola Pasar

Pendekatan personal tidak selamanya dapat menyelesaikan masalah dengan sempurna. Oleh karena itu, harus di imbangi dengan sosialisasi tentang peraturan-peraturan baik (PERDA) Peraturan Daerah maupun (PERWAL) Peraturan Wali Kota dan undang-undang yang menyangkut tentang tata tertib di Pasar. Sehingga harapannya tidak terjadi kesalah pahaman di dalam pelaksanaan kesehariannya. 


\section{Daftar Pustaka}

[1] Berg, Heinz-Peter, Risk Management: Procedures, Methods, and $\quad$ Experiences. Journal RT\&A, 2010.

[2] Darmawi, Herman, Manajemen Risiko Edisi 2. Jakarta, Bumi Aksara, hal82, 2016.

[3] Dahrendorf, Sosiologi Ilmu Pengetahuan Berparadigma, Ganada Rajawali Press, Jakarta, 1998.

[4] Fausett, L, Fundamentals of Neural Network, Prentice Hall, New York, 1994.

[5] Lexy J. Moleong, Metodologi Penelitian Kualitatif, Remaja Rosdakarya, Bandung, 2011.

[6] HR, Ridwan, Hukum Administrasi Negara, Rajawali Pers, Jakarta, 2006.

[7] Herdiansyah, Haris, Metode Penelitian Kualitatif untuk Ilmu-ilmu Sosial, Salemba Humanika, Jakarta, 2012.

[8] Moenir, Manajemen Pelayanan Publik, Bina Aksara,Jakarta, 2000.

[9] Ndraha, Ilmu Pemerintahan Baru, Rineka Cipta,Jakarta, 2003.

[10] Koentjaraningrat, Beberapa Pokok Antropologi Sosial, Dian Rakyat, Djakarta, 1967.

[11] Narwoko, J.D., dan Suyanto, B, Sosiologi Teks Pengantar dan Terapan, Kencana Prenada Media Group, Jakarta, 2005.

[12] Pasolong, H.,Teori Administrasi Publik, Alfabeta, Bandung, 2007.

[13] Republik Indonesia, UU No. 7 Tahun 2012 tentang Penanganan Konflik sosial, Lembaran Negara RI Tahun 2012, No. 116, Sekretariat Negara, Jakarta, 2012.

[14] Robbin, S.P., dan Judge, Perilaku organisasi, Jakarta,Salemba 2007. 